\title{
PENGARUH EPS, PER, CR, DAN ROE TERHADAP HARGA SAHAM DI BURSA EFEK INDONESIA
}

\author{
Pande Widya Rahmadewi ${ }^{1}$ \\ Nyoman Abundanti ${ }^{2}$
}

\author{
${ }^{1,2}$ Fakultas Ekonomi dan Bisnis Universitas Udayana, Bali, Indonesia \\ email: pandewidya@yahoo.co.id
}

\begin{abstract}
ABSTRAK
Harga saham sangat ditentukan dari penawaran dan permintaan akan saham itu sendiri. Semakin banyak orang yang membeli saham maka harga saham cenderung bergerak naik dan sebaliknya semakin banyak orang yang menjual sahamnya maka harga saham cenderung bergerak turun. Tujuan dari penelitian ini adalah untuk menganalisis signifikansi pengaruh EPS, PER, $C R$, dan ROE terhadap harga saham. Penelitian ini dilakukan pada Perusahaan Otomotif dan Komponen yang terdaftar di Bursa Efek Indonesia (BEI) periode 2012-2016. Jumlah sampel penelitian ini adalah 12 Perusahaan, dengan metode sampling jenuh yaitu semua populasi dijadikan sampel. Pengumpulan data dilakukan dengan metode observasi non partisipan. Berdasarkan hasil analisis ditemukan bahwa EPS, PER, CR, dan $R O E$ secara simultan berpengaruh signifikan terhadap harga saham. Secara parsial PER berpengaruh positif dan signifikan terhadap harga saham, hal ini menunjukkan bahwa investor memperhatikan PER dalam memustuskan untuk berivestasi. Semakin tinggi PER akan semakin tinggi juga minat investor dalam menanamkan modal pada perusahaan, sehingga harga saham akan ikut naik. Secara parsial EPS, CR, dan $R O E$ berpengaruh negatif terhadap harga saham hal ini menunjukkan bahwa investor tidak mempertimbangkan $E P S, C R$, dan $R O E$ sebagai keputusan untuk membeli saham.
\end{abstract}

Kata kunci: EPS, PER, CR, ROE, harga saham.

\begin{abstract}
The stock price is determined by the supply and demand of the stock itself. The more people who buy the stock then the stock price tends to move up and on the contrary more and more people are selling the stock then the stock price tends to move down. The purpose of this study is to analyze the significance of EPS, PER, CR, and ROE effects on stock prices. This research was conducted at Automotive Company and Component which listed in Indonesia Stock Exchange (BEI) period 2012-2016. The number of samples of this study is 12 companies, with saturated sampling method that is all the population sampled. Data collection was done by non participant observation method. Based on the analysis results found that EPS, PER, CR, and ROE simultaneously have a significant effect on stock prices. Partially, PER has positive and significant influence to stock price, it shows that investors pay attention to PER in order to make a divestment. The higher the PER will be the higher the investor's interest in investing in the company, so the stock price will go up. While the partial EPS, CR, and ROE have a negative effect on stock prices this shows that investors do not see EPS, CR, and ROE as a decision to buy shares.
\end{abstract}

Keywords: EPS, PER, CR, ROE, stock price 


\section{PENDAHULUAN}

Penilaian harga saham merupakan hal yang sangat penting dan mendasar bagi para investor sebelum melakukan investasi karena saham merupakan salah satu jenis investasi yang menjanjikan untuk para investor. Harga saham sangat ditentukan dari penawaran dan permintaan akan saham itu sendiri. Saham berwujud selembar kertas yang menerangkan bahwa pemilik kertas tersebut adalah pemilik perusahaan yang menerbitkan surat berharga tersebut. Fahmi (2012:81) yang dimaksud dengan saham adalah: "Tanda bukti penyertaan kepemilikan modal/dana pada suatu perusahaan, kertas yang tercantum dengan jelas nilai nominal, nama perusahaan dan diikuti dengan hak dan kewajiban yang dijelaskan kepada setiap pemegangnya, dan persediaan yang siap utuk dijual.”

Semakin banyak orang yang membeli saham maka harga saham cenderung bergerak naik dan sebaliknya semakin banyak orang yang menjual sahamnya makan harga saham cenderung bergerak turun. Jika harga saham meningkat maka kekayaan pemegang saham juga akan meningkat, begitu juga sebaliknya jika harga saham mengalami penurunan maka kekayaan pemegang saham juga akan mengalami penurunan.

Menurut Darmaji dan Fakhruddin (2012:149) ada dua metode yang dapat digunakan secara terpisah atau sekaligus dalam menganalisis saham, diantaranya adalah metode fundamental dan metode teknikal.

Metode fundamental merupakan salah satu cara untuk melakukan penilaian saham dengan mempelajari atau mengamati berbagai indikator yang terkait 
dengan kondisi makro ekonomi dan kondisi industri suatau perusahaan hingga berbagai indikator keuangan dan manajemen. Metode teknikal adalah salah satu metode yang digunakan untuk penilaian saham, dimana dengan metode ini para analisis melakukan evaluasi saham berbasis pada data-data statistik yang dihasilkan dari aktifitas perdagangan saham, seperti harga saham dan volume transaksi.

Sartono (2008:9), harga saham terbentuk dipasar modal dan ditentukan oleh beberapa faktor seperti laba per lembar saham atau Earning per Share (EPS), rasio laba terhadap harga per lembar saham atau Price Earning Ratio (PER), tingkat bunga bebas risiko yang diukur dari tingkat bunga deposito pemerintah dan tingkat kepastian operasi perusahaan. Selain faktor-faktor tersebut, harga saham juga dapat dipengaruhi oleh kondisi perusahaan. Semakin baik kinerja keuangan suatu perusahaan akan berdampak pada laba yang diperoleh perusahaan dan keuntungan yang didapat oleh investor, sehingga akan mempengaruhi peningkatan harga saham.

Sucipto (2013:6) Kinerja keuangan adalah penentuan ukuran-ukuran tertentu yang dapat mengukur keberhasilan suatu organisasi atau perusahaan dalam menghasilkan laba. Analisis kinerja keuangan sangat penting dilakukan untuk mengetahui apakah perusahaan tersebut merupakan perusahaan yang sehat, dan mampu menghasilkan laba sehingga investor dapat tertarik untuk menginvestasikan dana yang mereka miliki pada perusahaan tersebut. Semakin banyak investor yang tertarik membeli saham maka harga sahamnya akan naik. 
Darmaji dan Fakhruddin (2012:154) Earning per Share (EPS) merupakan rasio yang menunjukkan bagian laba untuk setiap saham. Kenaikan atau penurunan EPS dari tahun ke tahun adalah ukuran penting untuk mengetahui baik tidaknya pekerjaan yang dilakukan perusahaan pemegang sahamnya. EPS yang tinggi menandakan bahwa perusahaan dapat memberikan tingkat keuntungan kepada para pemegang saham, sebaliknya EPS yang lebih rendah memberikan tingkat keuntungan yang rendah kepada para pemegang saham. Secara teori semakin tinggi EPS, harga saham cenderung naik. EPS menggambarkan jumlah rupiah yang diperoleh untuk setiap lembar saham biasa dan prospek earnings perusahaan di masa depan. Secara teori semakin tinggi EPS, harga saham cenderung naik. EPS yang meningkat akan mendorong investor untuk menambah jumlah modal yang ditanamkan pada perusahaan tersebut, sehingga permintaan terhadap saham tersebut meningkat yang berakibat harga saham juga meningkat.

Menurut Menaje (2012) Earning per share (EPS) berpengaruh positif dan signifikan terhadap harga saham sesuai dengan pendapat Primayanti (2013), Dita (2013), Wang et al. (2013), Menike dan Prabath (2014), Ademola et al. (2016), Arif dan Wagar (2016) sedangkan Menurut Novasari (2013), Anita dan Pavitra (2014) Earning per Share (EPS) tidak memiliki pengaruh yang signifikan terhadap harga saham.

Price Earning Ratio (PER) menjelaskan perbandingan harga pasar dari setiap lembar saham terhadap EPS (laba per lembar saham).Menurut Tandelilin (2010:320) "Price Earning Ratio (PER) adalah rasio atau perbandingan antara harga saham terhadap earning perusahaan. Investor akan menghitung berapa kali 
nilai earning yang tercermin dalam harga suatu saham". Menurut Darmadji dan Fakhrudin (2012:198), menyatakan bahwa: “Price Earning Ratio menggambarkan apresiasi pasar terhadap kemampuan perusahaan dalam menghasilkan laba". Menurut Jogiyanto (2008:141) Price Earning Ratio (PER) yaitu: "Price Earning Ratio menunjukkan rasio dari harga saham terhadap earning. Rasio ini menunjukan berapa besar investor menilai harga dari saham terhadap kelipatan dari earning".Price earning ratio (PER) yang tinggi menunjukkan bahwa investor bersedia untuk membayar dengan harga saham premium atau dengan harga di atas harga pasar.Menurut Dita (2013) Price Earning Ratio (PER) berpengaruh positif signifikan terhadap harga saham sesuai dengan pendapat Primayanti (2013), Ademola etal., (2016), sedangkan menurut Novasari(2013), Prasetyo (2012), dan Ratri (2011) Price Earning Ratio (PER) tidak memiliki pengaruh yang signifikan terhadap harga saham.

Current Ratio $(C R)$ merupakan ukuran yang paling umum digunakan untuk mengetahui kesanggupan memenuhi kewajiban jangka pendek. Menurut Brigham dan Houston (2010:134) rasio lancar mengukur kemampuan aktiva lancar membayar hutang lancar. Aktiva lancar biasanya terdiri dari : kas, surat berharga, piutang, dan persediaan. Hutang lancar terdiri dari hutang dagang, wesel bayar jangka pendek, hutang jangka panjang yang segera jatuh tempo, pajak yang belum dibayar (accued) dan biaya-biaya yang belum dibayar (accrued) lainnya (terutama upah).

Current Ratio yang rendah menyebabkan terjadi penurunan harga pasar dari harga saham yang bersangkutan. Sebaliknya Current Ratio terlalu tinggi juga 
belum tentu baik, karena pada kondisi tertentu hal tersebut menunjukkan banyak dana perusahaan yang menganggur yang akhirnya dapat mengurangi keuntungan perusahaan. Menurut Dita (2013) Current Ratio (CR) berpengaruh positif signifikan terhadap harga saham sesuai dengan pendapat Kohansal et al. (2013) dan Dadrasmoghadam dan Akbar (2015) sedangkan menurut Ratri (2011) Current Ratio $(C R)$ tidak berpengaruh signifikan terhadap harga saham, sesuai dengan pendapat Antareka (2016), Nardi (2013), dan Bagherzadeh etal., (2013).

Menurut Brigham \& Houston (2010:149) berpendapat bahwa: "Pengertian Return on Equity adalah menjelaskan bahwa "pengembalian atas ekuitas biasa $(R O E)$ merupakan rasio laba bersih terhadap ekuitas biasa yang mengukur tingkat pengembalian atas investasi pemegang saham biasa." Kasmir (2012:204) Return on Equity (ROE) adalah rasio untuk mengukur laba bersih sesudah pajak dengan modal sendiri, sedangkan menurut Fahmi (2012:98) Return on Equity (ROE) adalah rasio yang digunakan untuk mengkaji sejauh mana suatu perusahaan mempergunakan sumber daya yang dimiliki untuk mampu memberikan laba atas ekuitas yang dimiliki.

Return on Equity (ROE) merupakan rasio yang digunakan untuk mengukur kemampuan dari modal sendiri untuk menghasilkan keuntungan bagi seluruh pemegang saham, bagi saham biasa maupun saham preferen. Semakin tinggi nilai $R O E$, tentunya akan menarik minat para investor untuk menanamkan modalnya pada perusahaan bersangkutan karena mengindikasikan bahwa perusahaan tersebut mempunyai kinerja yang baik dan akibatnya harga saham pun akan ikut tinggi. 
Menurut Ratri (2011) Return on Equity (ROE) berpengaruh signifikan dan positif terhadap harga saham, sesuai dengan pendapat Saleh (2015) Kohansal et al. (2013), Wang et al. (2013). Menurut Sukmawati dkk (2010) Return on Equity $(R O E)$ tidak memiliki pengaruh yang signifikan terhadap harga saham. Sedangkan menurut Setyorini dkk (2016) Return on Equity (ROE) berpengaruh negatif terhadap harga saham.

Perusahaan Otomotif merupakan perusahaan yang berkembang seiring dengan perkembangan jaman dan teknologi. Masyarakat Indonesia umumnya sangat konsumtif terhadap teknologi otomotif. Daya beli masyarakat Indonesia mendorong perusahaan otomotif yang terdaftar di Bursa Efek Indonesia (BEI) untuk memberikan kualitas terbaik mereka yang tentunya akan menarik banyak pihak salah satunya adalah investor, dengan kuliatas produk yang baik serta daya beli konsumen yang tinggi terhadap perusahaan otomotif dan komponen, tentunya para investor akan tertarik untuk menaruh sahamnya pada perusahaan tersebut.

Sektor otomotif dapat meningkatkan pendapatan negara dan dianggap penting serta strategis karena industri pendukung otomotif sangat luas karena meliputi industri besar, menengah dan kecil. Industri pendukung tersebut berada di hulu dan hilir antara lain seperti besi, baja, plastik, karet, kaca, tekstil, permesinan, suspensi, industri serat fiber, industri kimia, industri komputer dan telekomunikasi, elektronik dan industri komponen lainnya merupakan industri dasar bagi terbentuknya industri otomotif, sehingga industri ini dapat menyerap banyak tenaga kerja dan modal yang besar dan merata. Berikut disajikan data 
harga saham perusahaan Otomotif dan Komopen yang terdaftar di Bursa Efek Indonesia dari tahun 2012-2016:

Tabel 1.

Harga Saham Perusahaan Otomotif dan Komponen (Closing)

\begin{tabular}{ccccccc}
\hline No & $\begin{array}{c}\text { Kode } \\
\text { Perusahaan }\end{array}$ & $(\mathbf{R p}) \mathbf{2 0 1 2}$ & $(\mathbf{R p}) \mathbf{2 0 1 3}$ & $\begin{array}{c}\text { Tahun } \\
(\mathbf{R p}) \mathbf{2 0 1 4}\end{array}$ & $(\mathbf{R p}) \mathbf{2 0 1 5}$ & $(\mathbf{R p}) \mathbf{2 0 1 6}$ \\
\hline 1 & ASII & 7.600 & 6.800 & 7.425 & 6.000 & 8.275 \\
2 & AUTO & 3.548 & 3.650 & 4.200 & 1.600 & 2.050 \\
3 & BRAM & 3.000 & 2.250 & 5.000 & 4.680 & 6.675 \\
4 & GDYR & 1.230 & 1.900 & 1.600 & 2.725 & 1.920 \\
5 & GJTL & 2.225 & 1.680 & 1.425 & 530 & 1.070 \\
6 & IMAS & 5.300 & 4.900 & 4.000 & 2.365 & 1.310 \\
7 & INDS & 3.924 & 2.140 & 1.600 & 350 & 810 \\
8 & LPIN & 7.65 & 5.000 & 6.200 & 5.375 & 5.400 \\
9 & MASA & 450 & 390 & 420 & 351 & 270 \\
10 & NIPS & 113 & 323 & 487 & 425 & 354 \\
11 & PRAS & 255 & 185 & 204 & 125 & 170 \\
12 & SMSM & 2.525 & 3.450 & 4.750 & 4.760 & 980 \\
\hline Sumber: data Sekunder diolah, 2017 & & & &
\end{tabular}

Pada Tabel 1 harga saham pada Perusahaan Otomotif dan Komponen di Bursa Efek Indonesia dari tahun 2012-2016 mengalami perkembangan yang berfluktuatif dan perbedaan hasil penelitian terdahulu menjadi dasar dilakukannya penelitian lebih lanjut mengenai pengaruh Earning per Share (EPS), Price Earning Ratio (PER), Current Ratio (CR), Return on Equity (ROE) terhadap harga saham pada Perusahaan Otomotif dan Komponen yang terdaftar di Bursa Efek Indonesia (BEI).

Earning per Share (EPS) menunjukkan laba bersih yang berhasil diperoleh perusahaan untuk setiap lembar saham selama satu periode tertentu yang akan dibagikan kepada semua pemegang saham. Kenaikan atau penurunan EPS dari tahun ke tahun adalah ukuran penting untuk mengetahui baik tidaknya operasional 
yang dilakukan perusahaan. Secara teori semakin tinggi EPS, harga saham cenderung naik. EPS yang meningkat menandakan bahwa perusahaan tersebut berhasil meningkatkan taraf kemakmuran investor dan hal ini akan mendorong investor untuk menambah jumlah modal yang ditanamkan pada perusahaan tersebut. Pada akhirnya peningkatan jumlah permintaan terhadap saham mendorong harga saham juga ikut naik.

Menurut Dita (2013), Primayanti (2013),Mgbame dan Ohiorenuan (2013), Menike dan Prabath (2014), Menaje (2012), Wang et al. (2013) Ademola1 et al. (2016), Omokhududan Peter (2015), Rani dan Diantini (2015), Osundina et al.(2016), Arkan (2016) Earning per share (EPS) memiliki pengaruh positif dan signifikan terhadap harga saham.

$\mathrm{H}_{1}$ : Earning per share $(E P S)$ berpengaruh positif terhadap harga saham

Price earning ratio (PER) merupakan hubungan antara harga di pasar saham dengan earning per share saat ini yang digunakan secara luas oleh investor sebagai panduan umum untuk mengukur nilai saham. Price earning ratio (PER) yang tinggi menunjukkan bahwa investor bersedia untuk membayar dengan harga saham premium untuk perusahaan. Menurut Dita (2013), Primayanti (2013) dan Ademola et al. (2016) Price Price Earning Ratio (PER) berpengaruh positif dan signifikan terhadap harga saham.

$\mathrm{H}_{2}$ : Price earning ratio (PER) berpengaruh positif terhadap harga saham 
Rasio lancar adalah ukuran dari likuiditas jangka pendek. Rasio lancar perbandingan antara aset lancar dengan kewajiban lancar. Rasio ini menunjukkan kemampuan perusahaan untuk memenuhi kewajiban jangka pendeknya. Current Ratio yang rendah menyebabkan terjadi penurunan harga pasardari harga saham yang bersangkutan. Sebaliknya Current Ratio terlalu tinggi juga belum tentu baik, karena pada kondisitertentu hal tersebut menunjukkan banyakdana perusahaan yang menganggur yang akhirnya dapat mengurangi keuntungan perusahaan. Menurut Dita (2013), Kohansal et al. (2013), Dadrasmoghadam dan Akbar (2015) Current Ratio (CR) berpengaruh positif dan signifikan terhadap harga saham.

$\mathrm{H}_{3}$ : Current Ratio $(C R)$ berpengaruh positif terhadap harga saham

Return on Equity (ROE) merupakan salah satu rasio yang digunakan untuk mengukur profitabilitas suatu perusahaan. Rasio ini mengukur kemampuan perusahaan dalam menghasilkan keuntungan untuk diperhitungkan pengembalian perusahaan berdasarkan modal saham yang dimiliki oleh perusahaan. Jika $R O E$ semakin tinggi maka perusahaan dapat menghasilkan keuntungan dengan modal sendiri yang dapat menguntungkan para pemegang saham. Besar kecilnya nilai $R O E$ akan mempengaruhi pula harga saham perusahaan.

Semakin tinggi nilai $R O E$, tentunya juga akan menarik minat para investor untuk menanamkan modalnya pada perusahaan bersangkutan karena mengindikasikan bahwa perusahaan tersebut mempunyai kinerja yang baik dan akibatnya harga saham pun akan ikut tinggi. Dapat disimpulkan bahwa $R O E$ yang tinggi mengindikasikan harga saham yang tinggi dan ketika $R O E$ rendah 
mengindikasikan harga saham yang rendah. Menurut Ratri (2011), Saleh (2015) Kohansal et al. (2013), Wang et al. (2013), Arkan (2016) Return on Equity (ROE) berpengaruh positif dan signifikan terhadap harga saham.

$\mathrm{H}_{4}$ : Return on Equity (ROE) berpengaruh positif terhadap harga

\section{METODE PENELITIAN}

Metode ini digunakan untuk mengetahui hubungan antara rasio keuangan EPS, PER, CR, dan ROE terhadap harga saham pada Perusahaan Otomotif dan komponen yang terdaftar di Bursa Efek Indonesia (BEI) periode 2012-2016. Berdasarkan penjelasan mengenai hubungan antara rasio keuangan EPS, PER, $C R$, dan $R O E$ terhadap harga maka kerangka pemikiran teoritis dapat digambarkan model penelitian sebagai berikut:

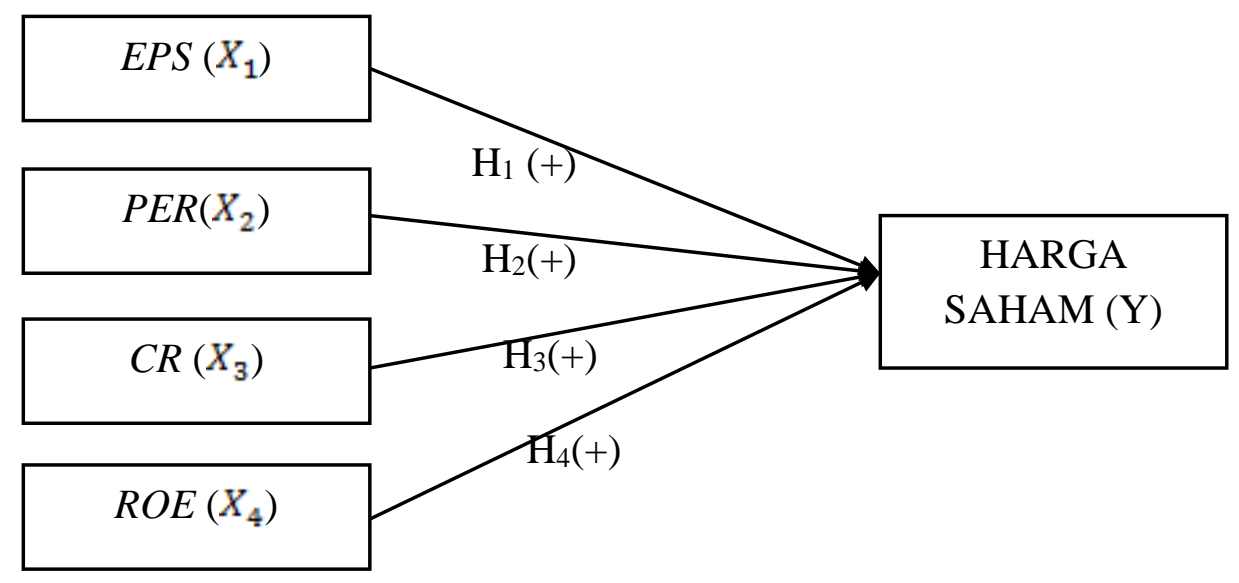

\section{Gambar 1. Model Penelitian}

Lokasi penelitian ini dilakukan pada Perusahaan Otomotif dan Komponen yang terdaftar di Bursa Efek Indonesia (BEI) dengan menggunakan laporan keuangan yang dipublikasikan pada website www.idx.co.id. Subyek dari penelitian 
ini adalah Perusahaan Otomotif dan komponen yang terdaftar di Bursa Efek Indonesia (BEI) periode 2012-2016. Obyek dari penelitian ini adalah rasio kinerja keuangan yang terdiri dari EPS, PER, CR, ROE, dan harga saham pada Perusahaan Otomotif dan komponen yang terdaftar di Bursa Efek Indonesia (BEI) periode 2012-2016. Variabel dependent (terikat) pada penelitian ini adalah harga saham. Variabel independent (bebas) yang digunakan dalam penelitian ini adalah $\operatorname{EPS}\left(\mathrm{X}_{1}\right)$, PER $\left(\mathrm{X}_{2}\right), C R\left(\mathrm{X}_{3}\right), \operatorname{ROE}\left(\mathrm{X}_{4}\right)$. Harga saham yang dimaksudkan dalam penelitian ini adalah harga saham pada saat penutupan (closing) pada Perusahaan Otomotif dan Komponen yang terdaftar di Bursa Efek Indonesia (BEI), periode 2012-2016.

Earning per Share (EPS) adalah kemampuan perusahaan untuk mendistribusikan pendapatan yang diperoleh kepada pemegang sahamnya. Satuan pengukuran EPS adalah Rupiah (Rp) yang ditunjukkan oleh laporan keuangan pada Perusahaan Otomotif dan Komponen yang terdaftar di Bursa Efek Indonesia (BEI) periode 2012-2016. EPS dapat dihitung dengan menggunakan rumus sebagai berikut (Wiagustini, 2014 :90)

$E P S=\frac{\text { lababersih }}{\text { lembar saham yang beredar }}$

Rasio ini menjelaskan perbandingan harga pasar dari setiap lembar saham terhadap EPS (laba per lembar saham), dalam rasio ini dihitung berapa kali nilai earning yang tercermin dalam harga saham. Satuan pengukuran PER adalah rupiah (Rp) yang ditunjukkan oleh laporan keuangan pada Perusahaan Otomotif 
dan komponen yang terdaftar di Bursa Efek Indonesia (BEI) periode 2012-2016. PER dapat dihitung menggunakan rumus (Wiagustini, 2014 :90)

$P E R=\frac{\text { harga saham }}{E P S}$

Rasio ini menunjukkan sejauh mana aktiva lancar menutupi kewajibankewajiban lancar. Satuan pengukuran $C R$ adalah persentase (\%) yang ditunjukkan oleh laporan keuangan pada Perusahaan Otomotif dan Komponen yang terdaftar di Bursa Efek Indonesia (BEI) periode 2012-2016. CR dapat dihitung menggunakan rumus (Wiagustini, 2014 :87)

$C R=\frac{\text { aktiva lancar }}{\text { kewajiban lanear }} \times 100 \%$

Tabel 2.

Perusahaan Otomotif dan Komponen yang terdaftar di BEI

\begin{tabular}{rlll}
\hline No & \multicolumn{1}{c}{$\begin{array}{c}\text { Kode } \\
\text { Perusahaan }\end{array}$} & \\
\hline & & & \\
& 1 & ASII & Astra Internasional Tbk \\
2 & AUTO & Astra Otoparts Tbk \\
3 & BRAM & Indo Kordsa Tbk \\
4 & GDYR & Goodyear Indonesia Tbk \\
5 & GJTL & Gajah Tunggal Tbk \\
6 & IMAS & Indomobil Sukses International Tbk \\
7 & INDS & Indospring Tbk \\
8 & LPIN & Multi Prima Sejahtera Tbk dh Lippo Enterprises Tbk \\
9 & MASA & Multistrada Arah Sarana Tbk \\
10 & NIPS & Nipress Tbk \\
11 & PRAS & Prima alloy steel Universal Tbk \\
12 & SMSM & Selamat Sempurna Tbk
\end{tabular}


Jenis data yang digunakan dalam penelitian ini adalah data kuantitatif, yaitu dari laporan keuangan dari Perusahaan Otomotif dan komponen yang terdaftar di Bursa Efek Indonesia (BEI) periode 2012-2016. Sumber data yang digunakan dalam penelitian ini adalah data sekunder, dalam hal ini adalah data yang sudah dipublikasikan oleh Perusahaan Otomotif dan komponen yang terdaftar di Bursa Efek Indonesia (BEI) periode 2012-2016.

Populasi dalam penelitian ini adalah semua Perusahaan Otomotif dan Komponen yang terdaftar di Bursa Efek Indonesia (BEI) periode 2012-2016. Pemilihan sampel penelitian ini dilakukan dengan menggunakan metode sampling jenuh (sampling sensus). Metode pengumpulan data yang digunakan dalam penelitian ini adalah pengumpulan data observasi non partisipan yaitu data laporan keuangan pada Perusahaan Otomotif dan komponen yang terdaftar di Bursa Efek Indonesia (BEI) periode 2012-2016.

\section{HASIL DAN PEMBAHASAN}

Pengujian hipotesis pada penelitian ini menggunakan model analisis regresi berganda. Sebelum dilakukannya analisis regresi berganda, maka model yang telah ditentukan diuji menggunakan uji asumsi klasik.

Uji Normalitas merupakan suatu alat uji yang digunakan untuk menguji apakah dari variabel-variabel yang digunakan dalam model regresi mempunyai distribusi normal atau tidak. Untuk mengetahui apakah data tersebut berdistribusi normal, dapat diuji dengan metode Kolmogorov Smirnov maupun pendekatan grafik. Model regresi yang baik adalah mempunyai distribusi data normal atau mendekati normal. 
Tabel 3.

Hasil Uji Normalitas

\begin{tabular}{|c|c|c|}
\hline & & $\begin{array}{l}\text { Unstandardiz } \\
\text { ed Residual }\end{array}$ \\
\hline $\mathrm{N}$ & & 60 \\
\hline \multirow[t]{2}{*}{ Normal Parameters ${ }^{\text {a.b }}$} & Mean & 0.0000000 \\
\hline & Std. Deviation & 113.05317102 \\
\hline Most Extreme & Absolute & 0.160 \\
\hline \multirow[t]{2}{*}{ Differences } & Povisitive & 0.160 \\
\hline & Negative & -0.131 \\
\hline Kolmogrorov-SmirnovZ & & 1.239 \\
\hline Asymp. Sig. (2-tailed) & & 0.093 \\
\hline
\end{tabular}

Berdasarkan Tabel 3 hasil pengujuian normalitas residual sudah berdistribusi normal, yang ditunjukkan dari nilai signifikansi Kolmogorov Smirnovsebesar 0,093 lebih besar dari 0,05. Hal ini berarti data residual terdistribusi normal.

Tabel 4.

Hasil Uji Multikolinieritas

\begin{tabular}{lll}
\hline Model & Collinearity Statistics & \\
& Tolerance & VIF \\
\hline EPS & 0.981 & 1.019 \\
PER & 0.957 & 1.045 \\
CR & 0.839 & 1.192 \\
ROE & 0.854 & 1.17 \\
\hline
\end{tabular}

Sumber: data sekunder diolah, 2017

Uji Multikolinieritas bertujuan untuk menguji apakah pada model regresi ditemukan adanya kolerasi antar variabel bebas. Model regresi yang baik seharusnya tidak terjadi kolerasi diantara variabel bebas atau bebas dari gejala multikolinier. Untuk mendeteksi ada atau tidaknya kolerasi antar sesama variabel bebas dapat dilihat dari nilai tolerance dan nilai variance inflation factor (VIF). 
Berdasarkan Tabel 4 dapat dijelaskan bahwa nilai tolerance dari EPS adalah 0,981, $P E R$ adalah $0,957, C R$ adalah 0,839 , dan $R O E$ adalah 0,854 yang mana hasil nilai tolerance diatas 0,10 . Hal ini berarti tidak ada kolerasi antar variabel bebas. Hasil perhitungan variance inflation factor (VIF) dari EPS adalah 1,019, PER adalah 1,045, $C R$ adalah 1,192 dan $R O E$ adalah 1,170 menunjukkan nilai VIF dibawah dari 10 yang juga berarti tidak ada kolerasi dari variabel bebas.

Uji Heteroskedastisitas bertujuan untuk menguji apakah model regersi terjadi ketidaksamaan varians dari residual satu pengamatan ke pengamatan lain. Model regresi yang baik adalah yang tidak mengandung gejala heteroskedastisitas atau mempunyai varians yang homogen.

Berdasarkan Tabel 5 terlihat bahwa signifikasi dari variabel EPS sebesar 0.292, PER sebesar 0,202,CR sebesar 0,701, dan ROE sebesar 0,069 menunjukkan nilai signifikasi lebih besar dari 0,05 yang artinya tidak ada pengaruh variabel bebas EPS, PER, CR, dan ROE terhadap absolut residual, sehingga layak dgunakan untuk memprediksi karena tidak mengandung gejala heteroskedastisitas.

Tabel 5.

Hasil Uji Heteroskedastisitas

\begin{tabular}{lrrr}
\hline \multicolumn{1}{c}{ Model } & Unstandardized Coefficients & \multicolumn{2}{c}{ Standardized Coefficients } \\
& B & Std. Error & Beta \\
\hline (constant) & 116.771 & 28.100 & -0.136 \\
EPS & -0.002 & 0.002 & -0.167 \\
PER & -0.072 & 0.056 & -0.053 \\
CR & -0.076 & 0.197 & -0.254 \\
ROE & -1.895 & 1.023 &
\end{tabular}

Sumber: data sekunder diolah, 2017 
Uji autokolerasi bertujuan untuk melacak adanya kolerasi auto atau pengaruh data dari pengamatan sebelumnya. Jika dalam suatu model regresi mengandung gejala autokolerasi, maka prediksi yang dilakukan dengan model tersebut akan tidak baik (bias), atau akan memberikan hasil prediksi yang menyimpang. Untuk mendeteksi terjadinya autokolerasi dalam penelitian ini dilakukan uji Durbin-Watsondengan melihat kolerasinya. Uji Durbin-Watson dihitung berdasarkan jumlah selisih kuadrat nilai taksiran faktor gangguan yang berurutan.

Tabel 6.

Hasil Uji Autokolerasi

\begin{tabular}{cccccc}
\hline Model & R & R Square & $\begin{array}{c}\text { Adjusted R } \\
\text { square }\end{array}$ & $\begin{array}{c}\text { Std. Error of } \\
\text { the Estimate }\end{array}$ & $\begin{array}{c}\text { Durbin- } \\
\text { Waston }\end{array}$ \\
\hline 1 & $0.576^{\mathrm{a}}$ & 0.331 & 0.283 & 117.092050 & 1.788 \\
\hline \multicolumn{2}{l}{ Sumber: data sekunder diolah, 2017} & & &
\end{tabular}

Berdasarkan Tabel 6 diatas diperoleh nilai Durbin-Watsonsebesar 1,788, dengan level of signifikan 5 persen, untuk $\mathrm{n}=60$ dan jumlah variabel bebas $(\mathrm{k})$ sebanyak $4, \mathrm{dL}=1,44$ dan $\mathrm{dU}=0,73$. Dengan demikian d statistik berada pada daerah tidak ada autokolerasi.

Tabel 7.

Hasil Regresi Linier Berganda

\begin{tabular}{|c|c|c|c|c|c|}
\hline \multirow[t]{2}{*}{ Model } & \multicolumn{2}{|c|}{$\begin{array}{l}\text { Unstandardized } \\
\text { Coefficients }\end{array}$} & \multirow{2}{*}{$\begin{array}{c}\text { Standardized } \\
\text { Coefficients } \\
\text { Beta } \\
\end{array}$} & \multirow[b]{2}{*}{$\mathbf{T}$} & \multirow[b]{2}{*}{ Sig } \\
\hline & B & Std. Error & & & \\
\hline (constant) & 174.864 & 47.091 & & 3.713 & 0.000 \\
\hline EPS & -0.002 & 0.003 & -0.068 & -0.613 & 0.542 \\
\hline PER & 0.365 & 0.094 & 0.437 & 3.879 & 0.000 \\
\hline $\mathrm{CR}$ & -0.433 & 0.331 & -0.158 & -1.309 & 0.196 \\
\hline ROE & -3.728 & 1.714 & -0.260 & -2.175 & 0.034 \\
\hline
\end{tabular}


Analisis regresi dilakukan untuk mengetahui bagaimana variabel dependen dapat diprediksi melalui variabel independen. Analisis regeresi yang digunakan dalam penelitian ini adalah analisis regresi linier berganda, dari analisis regersi linier berganda dapat dilihat pada tabel dibawah ini:

Berdasarkan Tabel 7 diperoleh persamaan regresi sebagai berikut:

$$
\mathrm{Y}=174,864-0,002 E P S+0,365 P E R-0,433 C R-3,728 R O E
$$

Nilai koefisien regresi variabel EPS $\left(\mathrm{X}_{1}\right)$ sebesar -0,002 nilai yang negatif menunjukkan adanya hubungan yang berlawanan antara harga saham dengan EPS, jika EPS meningkat sebesar satu satuan sementara variabel lainnya diasumsikan konstan atau sama dengan nol, maka harga saham akan menurun sebesar $-0,002$

Nilai koefisien regresi variabel PER $\left(\mathrm{X}_{2}\right)$ sebesar 0,365 nilai yang positif menunjukkan adanya hubungan yang searah anatara harga saham dengan PER jika variabel $P E R$ meningkat satu satuan sementara variabel lainnya dianggap konstan atau sama dengan nol maka harga saham akan meningkat sebesar 0,365

Nilai koefisien regresi variabel $C R\left(\mathrm{X}_{3}\right)$ sebesar $-0,433$ nilai yang negatif menunjukkan adanya hubugan yang berlawanan antara harga saham dengan $C R$ jika variabel $C R$ meningkat satu satuan sementara variabel lainnya dianggap konstan atau sama dengan nol maka harga saham akan menurun sebesar -0,433.

Nilai koefisien regresi variabel $R O E\left(\mathrm{X}_{4}\right)$ sebesar $-3,728$ nilai yang negatif menunjukkan adanya hubungan yang berlawanan antara harga saham dengan $R O E$ jika variabel $R O E$ meningkat satu satuan sementara variabel lainnya 
dianggap konstan atau sama dengan nol makam harga saham akan menurun sebesar $-3,728$.

Dari Tabel 8 dapat diketahui nilai $\mathrm{F}$ hitung sebesar 6,810 > F tabel 2,54 dan nilaisignifikasi sebesar $0,000<0,05$ maka hipotesis diterima. Hal ini berarti keempat variabel independen yaitu EPS, PER, $C R$, dan $R O E$ secara simultan berpengaruh signifikan terhadap variabel dependen yaitu harga saham.

Tabel 8.

Hasil Uji F

\begin{tabular}{llccccc}
\hline & & Sum of & & & & \\
\multicolumn{1}{c}{ Model } & Squares & Df & Mean Square & F & Sig \\
\hline 1 & Regression & 373461.7 & 4 & 93365.434 & 6.81 & $0.000^{\mathrm{a}}$ \\
& Residual & 754080.1 & 55 & 13710.548 & & \\
\multicolumn{2}{l}{ Total } & 1127542 & 59 & & &
\end{tabular}

Berdasarkan hasil uji t, maka dapat disimpulkan bahwa, hasil analisis Tabel 9 adalah:

Tabel 9.

Hasil Uji t

\begin{tabular}{lrrrrr}
\hline \multicolumn{1}{c}{ Model } & \multicolumn{2}{c}{$\begin{array}{c}\text { Unstandardized } \\
\text { Coefficients }\end{array}$} & $\begin{array}{c}\text { Standardized } \\
\text { Coefficients }\end{array}$ & & \\
& B & Std. Error & Beta & t & Sig \\
\hline (constant) & 174.864 & 47.091 & & 3.713 & 0.000 \\
EPS & -0.002 & 0.003 & -0.068 & -0.613 & 0.542 \\
PER & 0.365 & 0.094 & 0.437 & 3.879 & 0.000 \\
CR & -0.433 & 0.331 & -0.158 & -1.309 & 0.196 \\
ROE & -3.728 & 1.714 & -0.260 & -2.175 & 0.034 \\
\hline
\end{tabular}

Sumber: data sekunder diolah, 2017

Nilai signifikasi $0,542>0,05$ ini berarti hipotesis pertama ditolak, hal ini menunjukkan bahwa EPS tidak berpengaruh signifikan terhadap harga saham. 
Hipotesis diterima jika nilai signifikan $<0,05$. Nilai signifikansi $0,000<$ 0,05 ini berarti hipotesis kedua diterima, hal ini menunjukkan bahwa PER berpengaruh signifikan terhadap harga saham.

Hipotesis diterima jika nilai signifikan <0,05. Nilai signifikansi 0,196> 0,05 ini berarti hipotesis ketiga ditolak, hal ini menunjukkan bahwa $C R$ tidak berpenaruh signifikan terhadap harga saham.

Hipotesis diterima jika nilai signifikan $<0,05$. Nilai signifikansi $0,034<$ 0,05 ini berarti hipotesis keempat diterima, hal ini menunjukkan bahwa $R O E$ berpenaruh signifikan terhadap harga saham.

Dari tabel 10 diketahui nilai koefisien determinasi (Adjusted $R$ Square) adalah sebesar 0,283 atau sebesar 28,3\% hal ini menunjukkan bahwa pengaruh variabel independen yaitu EPS, PER, CR, dan ROE adalah sebesar 28,3\% terhadap variabel dependen yaitu harga saham dan sisanya $71,7 \%$ dipengaruhi oleh variabel lain yang tidak termasuk dalam model penelitian ini.

Tabel 10.

Koefisien Determinasi

\begin{tabular}{ccccc}
\hline Model & R & R Square & Adjusted R square & $\begin{array}{c}\text { Std. Error of the } \\
\text { Estimate }\end{array}$ \\
\hline 1 & $0.576^{\mathrm{a}}$ & 0.331 & 0.283 & 117.092050 \\
\hline Sumber: data sekunder diolah, 2017 & & &
\end{tabular}

\section{Pengaruh EPS terhadap Harga Saham}

Berdasarkan hasil pengujian parsial variabel EPS menunjukkan tidak ada pengaruh terhadap harga saham. Hal ini ditunjukkan dari nilai signifikasi 0,542> 0,05. Ini berarti bahwa investor tidak melihat EPS sebagai keputusan untuk membeli saham, sesuai dengan penelitian yang dilakukan oleh Cholidia (2017) 
bahwa investor cenderung tidak menggunakan analisis fundamental dalam pengambilan keputusan melainkan investor menggunakan kelompok referensi, pengalaman dan mengikuti pergerakan Bandar (spekulasi) dalam berinvestasi menunjukkan bahwa faktor psikologi dari investor mengambil peranan yang cukup penting dalam pengambilan keputusan investasi.Hasil penelitian ini konsisten dengan penelitian yang dilakukan oleh Novasari(2013), Anita dan Pavitra (2014), yang menegaskan bahwa EPS tidak memiliki pengaruh yang signifikan terhadap harga saham.

\section{Pengaruh PER terhadap Harga Saham}

Berdasarkan pengujian parsial variabel $P E R$ berpengaruh positif dan signifikan terhadap harga saham. Hal ini ditunjukkan dari nilai signifikansi 0,000 $<0,05$. PER mengindikasikan besarnya dana yang dikeluarkan oleh investor untuk memperoleh laba. Hasil penelitian ini menunjukkan bahwa investor memperhatikan PER dalam memustuskan untuk berivestasi. Semakin tinggi PER akan semakin tinggi juga minat investor dalam menanamkan modal pada perusahaan, sehingga harga saham akan ikut naik. Hasil penelitian ini sejalan dengan penelitian yang telah dilakukan oleh Dita (2013), Primayanti (2013), dan Ademola et al., (2016) PER berpengaruh positif dan signifikan terhadap harga saham.

\section{Pengaruh $C R$ terhadap Harga Saham}

Berdasarkan pengujian parsial variabel $C R$ tidak berpengaruh signifikan terhadap harga saham. Hal ini ditunjukkan dari nilai signifikansi 0,196 >0,05. Ini berarti investor tidak melihat $C R$ sebagai keputusan untuk membeli saham sesuai 
dengan penelitian oleh Cholidia (2017) bahwa faktor psikologi dari investor mengambil peranan yang cukup penting dalam pengambilan keputusan investasi dan tidak menggunakan analisis fundamental dalam pengambilan keputusannya. Hasil penelitian ini konsisten dengan penelitian yang telah dilakukan oleh Kundiman dan Hakim (2016) yang menegaskan bahwa $C R$ tidak berpengaruh signifikan terhadap harga saham.

\section{Pengaruh ROE terhadap Harga Saham}

Berdasarkan pengujian parsial variabel $R O E$ berpengaruh negatif dan signifikan terhadap harga saham. Ini ditunjukkan dari nilai signifikansi 0,034< 0,05. Ini berarti bahwa investor tidak melihat $R O E$ sebagai salah satu alasan untuk membeli saham sesuai dengan penelitian yang dilakukan oleh Cholidia (2017) bahwa investor cenderung tidak menggunakan analisis fundamental dalam pengambilan keputusannya melainkan menggunakan kelompok referensi, pengalaman dan mengikuti pergerakan bandar (spekulasi) dalam berinvestasi, menunjukkan bahwa faktor psikologi dari investor mengambil peranan yang cukup penting dalam pengambilan keputusan investasi.Hasil penelitian ini didukung oleh Perdana dkk (2013) dan Setyorini dkk (2016) yang menegaskan bahwa $R O E$ berpengaruh negarif dan signifikan terhadap harga saham.

Implikasi Teoritis, Earning per Share (EPS), Current Ratio (CR), dan Return on Equity (ROE), berpengaruh negatif terhadap harga saham kecuali Price Earning Ratio (PER) berpengaruh positif terhadap harga saham. Hal ini menunjukkan bahwa variabel fundamental perusahaan tidak terbukti mempengaruhi investor untuk berinvestasi di pasar modal, kondisi ini disebabkan 
oleh faktor psikologi investor, sesuai dengan penelitian yang dilakukan oleh Cholidia (2017). Price Earning Ratio (PER) berpengaruh positif terhadap harga saham. Hal ini menunjukkan bahwa PER menjadi satu-satunya yang diperhatikan oleh investor dalam berinvestasi di pasar modal, sesuai dengan penelitian yang telah dilakukan oleh Dita (2013), Primayanti (2013), dan Ademola et al. (2016).

Penelitian ini menghasilkan informasi bahwa PER berpengaruh positif terhadap harga saham yang berarti investor memperhatikan PER dalam melakukan investasi. Semakin tinggi PER maka akan semakin tinggi juga minat investor dalam menanamkan modal pada perusahaan, sehingga harga saham juga akan ikut naik.

Earning per Share (EPS), Current Ratio (CR), dan Return on Equity $(R O E)$, berpengaruh negatif terhadap harga saham kecuali Price Earning Ratio (PER) berpengaruh positif terhadap harga saham. Hal ini menunjukkan bahwa variabel fundamental perusahaan tidak terbukti mempengaruhi investor untuk berinvestasi di pasar modal. Investor lebih menggunakan faktor psikologi yang tercermin dari penggunaan pengalaman, kelompok referensi dan tindakan spekulasi dalam pengendalian keputusan untuk berivestasi di pasar modal, sesuai dengan penelitian yang dilakukan oleh Cholidia (2017).

Price Earning Ratio (PER) berpengaruh positif terhadap harga saham. Hal ini menunjukkan bahwa PER menjadi satu-satunya yang diperhatikan oleh investor dalam berinvestasi di pasar modal, sesuai dengan penelitian yang telah dilakukan oleh Dita (2013), Primayanti (2013), dan Ademola et al (2016). 
Penelitian ini menghasilkan informasi bahwa $P E R$ berpengaruh positif terhadap harga saham yang berarti investor memperhatikan PER dalam melakukan investasi. Semakin tinggi PER maka akan semakin tinggi juga minat investor dalam menanamkan modal pada perusahaan, sehingga harga saham juga akan ikut naik.

\section{SIMPULAN DAN SARAN}

Dari hasil analisis data, pengujian hipotesis dan pembahasan, maka dapat ditarik kesimpulan dari penelitian ini sebagai berikut, terdapat hubungan yang negatif dan tidak signifikan antara variabel Earning per Share (EPS) dengan harga saham, ini berarti bahwa investor tidak melihat EPS sebagai keputusan untuk membeli saham.Variabel Price Earning Ratio (PER) berpengaruh positif dan signifikan terhadap harga saham. Semakin tinggi $P E R$ akan semakin tinggi juga minat investor dalam menanamkan modal pada perusahaan, sehingga harga saham akan ikut naik.

Terdapat hubungan yang negatif dan tidak signifikan anatara variabel Current Ratio $(C R)$ terhadap harga saham, ini berarti bahwa investor tidak melihat $C R$ sebagai keputusan untuk membeli saham.Variabel Return on Equity (ROE) berpengaruh negatif dan signifikan terhadap harga saham, ini berarti bahwa investor tidak melihat ROE sebagai keputusan dalam membeli saham.

Bagi perusahaan, disarankan agar lebih meningkatkan profitabilitas perusahaan karena dengan meningkatkan profitabilitas perusahaan maka juga akan meningkatkan $P E R$, jika $P E R$ meningkat maka akan menarik banyak investor untuk menanamkan modal di perusahaan sehingga harga saham akan ikut 
meningkat. Bagi investor agar menggunakan PER dalam alternatif untuk melakukan investasi, karena $P E R$ berpengaruh positif dan signifikan terhadap harga saham, semakin tinggi PER maka minat investor dalam menanamkan modal juga semakin tinggi dan harga saham juga akan ikut naik.

\section{REFERENSI}

Anita dan Pavitra Yadav. 2014. Influence of Selected Financial Indicators on Stock Price of Tata Motors Ltd. International Journal of Application or Innovation in Engineering \& Management (IJAIEM), 3(1): 49-252.

Antareka, Lena. 2016. Pengaruh Current Ratio (CR), Return On Assets (ROA), Earning Per Share (EPS), dan Net Profit Margin (NPM) terhadap Harga Saham Perusahaan Real Estate And Property Yang Terdaftar di Bursa Efek Indonesia Periode 2010-2014. Skripsi.

Arif, Kashif dan Waqar Akbar. 2016. Impact of Accounting Information on Share Price: Empirical Evidence from Pakistan Stock Exchange. International Finance and Banking, 3(3): 124-135.

Arkan, Thomas. 2016. The Importance of Financial Ratios in Predicting Stock Price Trends: a Case Study in Emerging Markets. Finanse, Rynki Finansowe, Ubezpieczenia, 1 (79): 13-26.

Bagherzadeh, Mohammad Reza et., al. 2013.Relationship between Current ratio and Share Price - a study on NSE, INDIA (2009-2012). Int Jr. of Mathematical Sciences \& Applications, 3(1): 163-167.

Brigham, Eugene dan Joel F Houston, 2010. Manajmeen Keuangan II. Jakarta: Selemba Empat.

Cholidia, Rifatin. 2017. Perilaku Investor dalam Pengambilan Keputusan Investasi di Pasar Modal (Studi Kasus pada Investor Saham Individu di Bandar Lampung). Skripsi.

Dadrasmoghadam, Amir and Seyed Mohammad Reza Akbar. 2015. Relationship between Financial Ratios in the Stock Prices of Agriculture-Related Companies Accepted On the Stock Exchange for Iran. Research Journal of Fisheries and Hydrobiology,3(1): 586-591.

Darmaji, Tjiptono, dan Fakhruddin. 2012. Pasar Modal di Indonesia. Edisi Ketiga. Jakarta: Selemba Empat 
Dita, Ines Farah. 2013. Pengaruh Kinerja Keuangan terhadap Harga Saham (Studi pada Perusahaan Otomotif yang terdaftar di Bursa Efek Indonesia (BEI) periode 2009-2011. Skripsi.

Fahmi, Irhan, dan Hadi. 2011. Teori Portofolio dan Analisis Investasi. Edisi Kedua. Bandung: Alfabeta.

Jogiyanto. 2008. Teori Portofolio dan analisis Investasi. Edisi kelima. Yogyakarta: BPFE.

Kasmir. 2012. Analisis Laporan Keuangan. Jakarta: Raja Grafindo.

Kohansal et.,al. 2013. Relationship between Financial Ratios and Stock Prices for the Food Industry Firms in Stock Exchange of Iran. World Applied Programming, 1(3): 512-521.

Kundiman dan Hakim. 2016. Pengaruh Current Ratio, Debt to Equity Ratio, Return on Asset, Return on Equity terhadap Harga Saham pada Indeks LQ 45 di BEI Periode 2010-2014. Among Makarti, 9(18): 80-98.

Menaje, Placido M. Jr. 2012. Impact of Selected Financial Variables on Share Price of Publicly Listed Firms in the Philippines. American International Journal of Contemporary Research, 2(1): 98-104.

Menike dan Prabath. 2014. The Impact of Accounting Variables on Stock Price: Evidence from the Colombo Stock Exchange, Sri Lanka. International Journal of Business and Management, 9(1): 125-137.

Mgbame, C.O. dan Ohiorenuan Jude Ikhatua. 2013. Accounting Information and Stock Volatility in the Nigerian Capital Market: A Garch Analysis Approach. International Review of Management and Business Research, 1(2): 265-281.

Nardi. 2013. Pengaruh Current Ratio (CR), Debt To Equity Ratio (DER), Net Profit Margin (NPM), DAN Return On Investment (ROI) terhadap Harga Saham Pada Perusahaan Food And Beverages Yang Terdaftar di BEI. Skripsi.

Novasari, Ema. 2013. Pengaruh PER, EPS, ROA dan DER terhadap Harga Saham Perusahaan Sub-Sektor Industri Textile Yang Go Public Di Bursa Efek Indonesia (BEI) Tahun 2009-2011.Skripsi.

Omokhudu,Okuns Omokhoje dan Peter Okoeguale Ibadin. 2015. The Value Relevance of Accounting Information: Evidence from Nigeria. Accounting and Finance Research, 1(4): 21-30. 
Osundina, J. Ademola1, Jayeoba, Olajumoke O., Olayinka, Ifayemi M. 2016. Impact of Accounting Information on Stock Price Volatility (A Study of Selected Quoted Manufacturing Companies in Nigeria). International Journal of Business and Management Invention. 1(5): 41-54.

Perdana dkk. 2013. Pengaruh Return on Equity (ROE), Earning per Share (EPS), dan Debt Equity Ratio (DER) terhadap Harga Saham. Jurnal Administrasi dan Bisnis (JAB), 2(1): 218-137.

Prasetyo, Eko 2012. Pengaruh Earning per Share (EPS). dan Price Earning Ratio (PER) terhadap Harga Saham pada Perusahaan LQ-45 yang terdaftar di Bursa Efek Indonesia. Skripsi.

Primayanti, Diensa. 2013. "Pengaruh Kinerja Keuangan Perusahaan terhadap Harga Saham (studi empiris pada Perusahaan Manufaktur yang terdaftar di BEI tahun 2010-2011). ejurnal Universitas Muhammadiah Surakarta, 2(1): 1-13.

Rani, Kadek Stia dan Ni Nyoman Ayu Diantini. 2015. Pengaruh Kinerja Keuangan Perusahaan terhadap Harga Saham dalam Indeks LQ45 di BEI. e-jurnal Manajemen Unud, 4: 1526-1542.

Ratri, Teska Destia. 2015. "Pengaruh Kinerja Keuangan terhadap Harga Saham Perusahaan Tekstik dan Produk Tekstil (TPT) yang terdaftar di Busra Efek Indonesia (BEI) tahun 2009-2014”.Skripsi.

Saleh,Muhammad. 2015. Relationship between Firm's Financial Performance and Stock Returns: Evidence from Oil and Gas Sector Pakistan. Journal of Energy Technologies and Policy, 5: 27-32.

Sartono, R.A. 2008. Manajemen Keuangan Teori dan Aplikasi. Yogyakarta: BPFE.

Setyorini, Maria M Minarsih, Andi Tri Haryono. 2016. Pengaruh Return on Assets (ROA), Return on Equity (ROE), Dan Earning Per Share (EPS) Terhadap Harga Saham Perusahaan Real Estate di Bursa Efek Indonesia (Studi Kasus pada 20 Perusahaan Periode 2011-2015).Journal of Management, 2(2): 1-12.

Sucipto. 2013. "Penilaian Kinerja Keuangan." Ekonomi dan Bisnis, FE. Universitas Sumatra Utara: Medan.

Sukmawati, Surviaratih. 2010. Pengaruh Earning Per Share (EPS) Dan Return On Equity (ROE) Terhadap Harga Saham (Survei Penelitian Pada Perusahaan Industri Rokok Yang Go Public di Bursa Efek Indonesia) 
E-Jurnal Manajemen Unud, Vol. 7, No. 4, 2018: 2106-2133

Sunariyah, 2011. Pengantar Pengetahuan Pasar Modal. Edisi Keenam. Yogyakarta: UPP STIM YKPN.

Tandelilin, Eduardus. 2010. Portofolio dan Investasi (Teori dan Aplikasi). Edisi Pertama. Yogyakarta : Kanisius.

Wang, Junjie et.,al. 2013. Accounting Information and Stock Price Reaction of Listed Companies - Empirical Evidence from 60 Listed Companies in Shanghai Stock Exchange. Journal of Business \& Management, 1(2): 1121.

Wiagustini, Ni Luh Putu. 2014. Manajemen Keuangan. Denpasar: Udayana Univesrsity Press. 